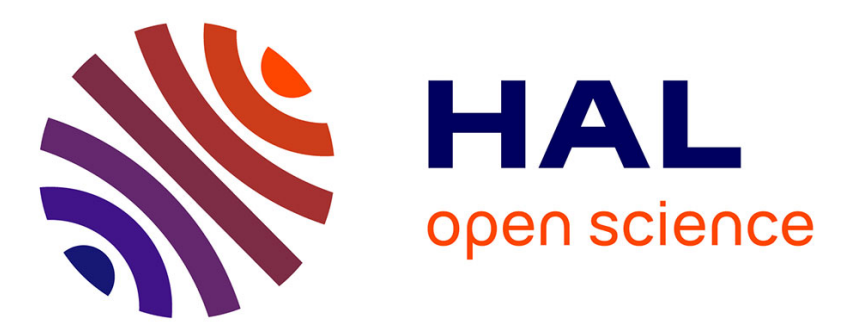

\title{
Evaluation of bioavailable hydrocarbon sources and their induction potential in Prince William Sound, Alaska
}

Kathrine R. Springman, Jeffrey W. Short, Mandy Lindeberg, Stanley D. Rice

\section{To cite this version:}

Kathrine R. Springman, Jeffrey W. Short, Mandy Lindeberg, Stanley D. Rice. Evaluation of bioavailable hydrocarbon sources and their induction potential in Prince William Sound, Alaska. Marine Environmental Research, 2008, 66 (1), pp.218. 10.1016/j.marenvres.2008.02.064 . hal-00563025

\section{HAL Id: hal-00563025 https://hal.science/hal-00563025}

Submitted on 4 Feb 2011

HAL is a multi-disciplinary open access archive for the deposit and dissemination of scientific research documents, whether they are published or not. The documents may come from teaching and research institutions in France or abroad, or from public or private research centers.
L'archive ouverte pluridisciplinaire HAL, est destinée au dépôt et à la diffusion de documents scientifiques de niveau recherche, publiés ou non, émanant des établissements d'enseignement et de recherche français ou étrangers, des laboratoires publics ou privés. 


\section{Accepted Manuscript}

Evaluation of bioavailable hydrocarbon sources and their induction potential in Prince William Sound, Alaska

Kathrine R. Springman, Jeffrey W. Short, Mandy Lindeberg, Stanley D. Rice

PII: S0141-1136(08)00093-7

DOI: 10.1016/j.marenvres.2008.02.064

Reference: MERE 3239

To appear in: Marine Environmental Research

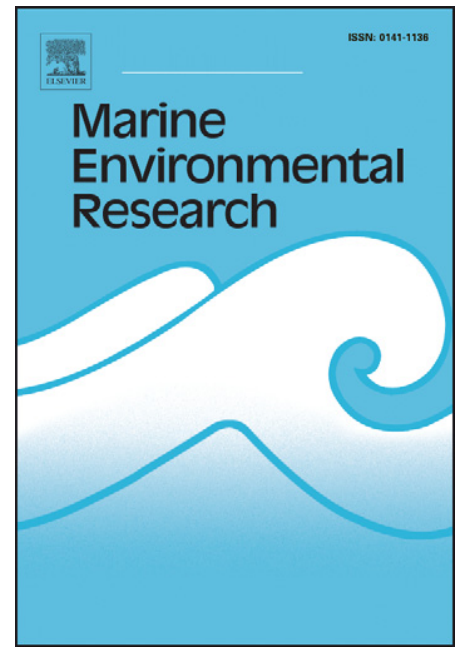

Please cite this article as: Springman, K.R., Short, J.W., Lindeberg, M., Rice, S.D., Evaluation of bioavailable hydrocarbon sources and their induction potential in Prince William Sound, Alaska, Marine Environmental Research (2008), doi: 10.1016/j.marenvres.2008.02.064

This is a PDF file of an unedited manuscript that has been accepted for publication. As a service to our customers we are providing this early version of the manuscript. The manuscript will undergo copyediting, typesetting, and review of the resulting proof before it is published in its final form. Please note that during the production process errors may be discovered which could affect the content, and all legal disclaimers that apply to the journal pertain. 


\title{
Evaluation of bioavailable hydrocarbon sources and their induction potential in Prince William Sound, Alaska
}

\author{
Kathrine R. Springman ${ }^{\text {a }}$, Jeffrey W. Short ${ }^{\text {b }}$, Mandy Lindeberg ${ }^{\text {b }}$, Stanley D. \\ Rice $^{b}$ \\ ${ }^{a}$ University of California Davis, Davis, California, USA \\ ${ }^{b}$ Auke Bay Laboratory, NOAA/NMFS, Juneau, Alaska, USA
}

\begin{abstract}
To realistically evaluate the consequences of exposure to a complex mixture, we modified a passive sampler technology, the semipermeable membrane device (SPMD), which absorbs the bioavailable hydrophobic organic compounds present in an environment. These samplers were deployed in Prince William Sound (PWS), Alaska, at locations selected as potential sites of hydrocarbon deposition, as well as in random sites for regional assessment. Some of these sites were affected by previous human activity, such as canneries and salmon hatcheries, while others were sites of oil discharge as a consequence of the 1964 earthquake or the oil spill of T/V Exxon Valdez in 1989. The SPMDs were deployed for 27- $28 \mathrm{~d}$, processed, and then split, with one aliquot dedicated to chemical analysis and the other injected into juvenile rainbow trout
\end{abstract}




\section{ACCEPTED MANUSCRIPT}

(Oncorhynchus mykiss), along with the proper controls including a solvent control, field blank, and positive control. Trout fry were sacrificed after 2 or $7 \mathrm{~d}$, and their livers assayed for CYP1A induction by the standard bioassay for hydrocarbon exposure, the ethoxyresorufin-o-deethylase (EROD) assay. The results of this study were consistent and reproducible and showed that oil, whether deposited in 1964 or 1989, is still bioavailable as it can elicit as sustained response. Also, the same oil deposited in different sites of the same region has degraded differently, which is demonstrated by this method. Other putative sources of hydrocarbons, such as oil seeps, were dismissed as regional sources of induction agents as the responses following injection of modified SPMD extract from those sites did not differ significantly from the solvent control. This is a flexible, sensitive method that assesses the response to site-specific bioavailable contaminants and does so within the normal physiological response range of the target.

Keywords: Complex mixture; EROD; Oil spill; SPMD; CYP1A; Assessment Corresponding author: krspringman@gmail.com (K.R. Springman)

One of the goals of environmental toxicology is to replicate the consequences of contaminant exposure in organisms without the confounding effects of other variables in the environment. This is particularly true for trace levels of hydrophobic compounds found in complex contaminant mixtures. With the advent of passive samplers such as the semipermeable membrane device (SPMD), monitoring low, yet biologically significant, concentrations of bioavailable hydrophobic organic contaminants became possible (Huckins et al., 1993; Rantalainen et al., 1998). These devices have become a well-documented method of assessing the bioavailable fraction of contaminants in water, soil, sediment or air, (Johnson et al., 2000; 


\section{ACCEPTED MANUSCRIPT}

Petty et al., 2000) and have improved toxicity profiling over the practice of chemically extracting hydrophobic compounds, compiling lists of potentially toxic contaminants and assessing their combined effects based on laboratory exposure data. The U.S. Geological Survey (USGS) describes the SPMD as the "virtual fish" that does not metabolize or depurate contaminants it encounters in its aquatic environment, nor is it susceptible to disease or predation (http://wwwaux.cerc.cr.usgs.gov/spmd/). This technology was adapted to expose organisms to the SPMD extract and to assess its effects. This modification links the bioavailable hydrophobic compounds, as encountered in situ, to the biochemical effects this mixture may elicit.

In this study we tested the applicability of this approach for assessing biomarker responses to contaminants found at sites, some of which were impacted many years prior by an oil spill, throughout the Sound. The biomarker chosen was the induction of CYP1A, an enzyme involved in the breakdown of planar hydrocarbons such as polycyclic aromatic hydrocarbons (PAH), and some polychlorinated biphenyls (PCB). The induction of this substrate-inducible enzyme is a well-documented and sensitive biomarker of exposure to petroleum compounds (Stegeman and Hahn, 1994). Other potential sources of CYP1A inducing hydrocarbons may be found in the Sound in addition to lingering oil from the Exxon Valdez oil spill in 1989. These include possible atmospheric transport of persistent organic pollutants such as polychlorinated biphenyls (PCB), some of which could induce this enzyme. Returning salmon may also serve as a source of contaminants released from their carcasses following spawning in their native streams (Krümmel et al., 2003). Native oil seeps that are located southeast of PWS could release hydrocarbons that may be transported to PWS via the Alaska Coastal Current. Abandoned industrial sites, salmon hatcheries, and harbors representative of the regional marine boating traffic were selected to evaluate all potential sources of CYP1A-inducing compounds. To assess background conditions and evaluate potential atmospheric transport of contaminants to PWS, we 


\section{ACCEPTED MANUSCRIPT}

used Alaska Department of Fish and Game (ADF\&G) management districts as geographic divisions of the Sound and placed samplers at 30 sites randomly through these 5 divisions. In total, 53 sites were selected, and with replication, 80 deployments of SPMDs were placed in the mid-intertidal zone for 27-28 d, the standard deployment period for these samplers.

The SPMDs used in this work were obtained from Environmental Sampling Technologies (EST, St. Josesph, MO). These SPMDs had standard specifications (Table 1).

Deployment devices were loaded with 5 SPMDs per device and placed at the selected sites. In order to minimize biofouling and anchor the samplers, the deployment devices were placed in the intertidal zone halfway embedded in the sand, gravel or cobble surface using duckbill anchors.

The methods used in this study are described in detail elsewhere (Springman et al., in press). Briefly, the samplers were processed as described in Huckins et al., 2000. Following dialysate concentration, the samples were split in two aliquots, one for analysis and the other for toxicological testing. All remaining hexane was removed from the latter, and it was resuspended in peanut oil (Sigma, St. Louis, MO). Other samples were prepared for injection and analysis as well. The controls included the field blanks, samples of the oil used for resuspending the extracts, and peanut-oil suspended $\beta$-naphthoflavone (BNF), a model CYP1A inducer and the positive control.

Mount Shasta strain rainbow trout juveniles (Oncorhynchus mykiss), average weight 9.2 g, were obtained from California Department of Fish and Game Hatchery, Mount Shasta, California, and held in aerated $13 \pm 1{ }^{\circ} \mathrm{C}$ flowing water. Fish were not fed the day prior to dosing. Individuals were anesthetized in a solution of $\sim 50 \mathrm{mg} / \mathrm{l}$ tricaine methane sulfonate (MS222; Argent Chemical Laboratories, Redmond, WA), and injected intraperitoneally with 50 $\mu \mathrm{l}$ doses of SPMD extracts in peanut oil with 10 fish per group. After an induction period of $2 \mathrm{~d}$, 


\section{ACCEPTED MANUSCRIPT}

5 fish from each group were sacrificed in an overdose of MS222, the remainder sacrificed after 7

d. The liver was carefully excised and frozen in liquid nitrogen and used in the ethoxyresorufin$o$-deethylase (EROD) bioassay. The methods used are described in Springman et al. (in press).

The frequency distributions of EROD responses associated with the uncontaminated sites are approximately log-normal; consequently, parametric statistical analyses of log-transformed EROD responses is justified.

As shown in Fig. 1, both sets of controls (not handled and solvent control) are in agreement with each other and the EROD results from Constantine Harbor, a site that is rarely used. Concurrence between the positive EROD control (BNF) results and those of Knight Island, a site that was oiled in the Exxon Valdez oil spill, is clear. The results from the positive environmental control or contaminated site (Cordova Harbor) are less than those of either oiled site. Of note is that the levels of induction from bioavailable CYP1A inducers found at Disk Island after 15 years exceed both the positive environmental control and the positive EROD control. Random site responses were not significantly different from each other, and when pooled were also not significantly different from the corresponding peanut oil or field blank responses (permutation test $P=0.383$, two-tailed pairwise comparison) (Springman et al., in press).

This study produced results which clearly demonstrate the value of this method in estimating hydrocarbon exposure effects. Its sensitivity is demonstrated in the small differences, such as those between spring and summer salmon stream EROD activities, which are internally consistent (Short et al., in press). Its dynamic range is broad enough to capture and differentiate these distinctions while quantifying the exposure effects following direct exposure to bioavailable oil. The reproducibility of the results obtained using this method is demonstrated by the biochemical responses from the oiled sites, particularly EL056C as the replicates were meters 


\section{ACCEPTED MANUSCRIPT}

apart. It is a reliable, sensitive method of evaluating exposure to the bioavailable fraction of hydrophobic contaminants, as the response elicited is based on the contaminants' absorption into the SPMD, which serves as a surrogate for the targets. Constraints and caveats in the application of this method, including quantification and dosage, are thoroughly discussed elsewhere (Springman et al., in press), and the complementary analytical results are found in Short et al. (in press).

This method complements field testing of biota from contaminated areas as it measures the response that the bioavailable contaminant fraction can produce with few confounding variables. However, the method does not address uptake or variations based on gender, age, reproductive status or condition. In this case, CYP1A induction was selected as it is a wellestablished method of hydrocarbon exposure assessment. For breadth of applicability the test organism used in this study was an appropriate choice as rainbow trout P450 systems may be as complex as their mammalian counterparts (Buhler and Wang-Buhler, 1998). Ultimately, the suspected nonpolar contaminants and the potential targets determine which response(s) to measure and which test organism to use, but the method presented here is flexible and can accommodate other types of analysis and different test animals. The merits of linking SPMDs with the effects their contents elicit were recognized by Sabaliunas et al. (1998), “...integration of the SPMD technique and bioassays may be a valuable approach for the assessment of levels and effects of bioavailable hydrophobic pollutants." The technique presented here accomplished this and goes one step further by connecting bioavailable contaminants to the target's biological response in a consistent manner. 


\section{ACCEPTED MANUSCRIPT}

\section{References}

Buhler, D. R., and Wang-Buhler, J.-L. (1998) Comparative Biochemistry and Physiology Part C, $121,107-137$.

Huckins,J.N., Manuweera,G.K., Petty,J.D., Mackay,D., and Lebo,J.A. (1993) Environmental Science and Technology, 27, 2489-2498.

Huckins, J.N., Petty, J.D., Prest, H.F., Clark, R.C., Alvarez, D.A., Orazio, C.E., et al. (2000). A Guide for the Use of Semipermeable Membrane Devices (SPMDs) as Samplers of Waterborne Hydrophobic Contaminants. U.S. Geological Survey, Columbia Environmental Research Center, Columbia, MO.

Krümmel,E.M., Macdonald,R.W., Kimpe,L.E., Gregory-Eaves,I., Demers,M.J., Smol,J.P., et al. (2003). Nature, 425, 255-256.

Johnson,B.T., Huckins,J.N., Petty,J.D., and Clark,R.C. (2000). Environmental Toxicology, 15, 248-252.

Petty,J.D., Orazio,C.E., Huckins,J.N., Gale,R.W., Lebo,J.A., Meadows,J.C., et al. (2000). Journal of Chromatography A, 879, 83-95.

Rantalainen, A.-L., Ikonomou, M.G., and Rogers, I.H. (1998). Chemosphere, 37, 1119-1138.

Sabaliūnas, D., Lazutka, J., Sabliūnienë, I., and Södergren, A. (1998). Environmental Toxicology and Chemistry, 17, 1815-1824.

Short, J.W., Springman, K.S., Lindeberg, M.R., Maselko, J., Khan, C., Hodson, P.V., et al. (in press).

Springman, K.R., Short, J.W., Lindeberg, M.R., Maselko, J., Khan, C., Hodson, P.V. et al. (in press). 


\section{ACCEPTED MANUSCRIPT}

Stegeman, J. J., and Hahn, M. E. (1994) In: Aquatic Toxicology: Molecular, Biochemical and Cellular Perspectives, Malins, D. C., Ostrander, G. K., Eds.; Lewis Publishers: Boca Raton, Florida; pp 87-206. 


\section{Figure caption}

Fig. 1. CYP1A Induction from Prince William Sound SPMD Extracts, Selected Sites. Treatments, left to right: Knight Island and Disk Island are sites in Prince William Sound that were oiled in 1989 by the Exxon Valdez spill. Cordova and Chenega are positive environmental controls, and Constantine Harbor is downstream from a natural oil seep. Following these are controls: oil only, unhandled procedural control, and EROD positive control, BNF ( $\beta$ naphthoflavone, a model CYP1A inducer, $2.5 \mathrm{mg} / \mathrm{kg}$ ).

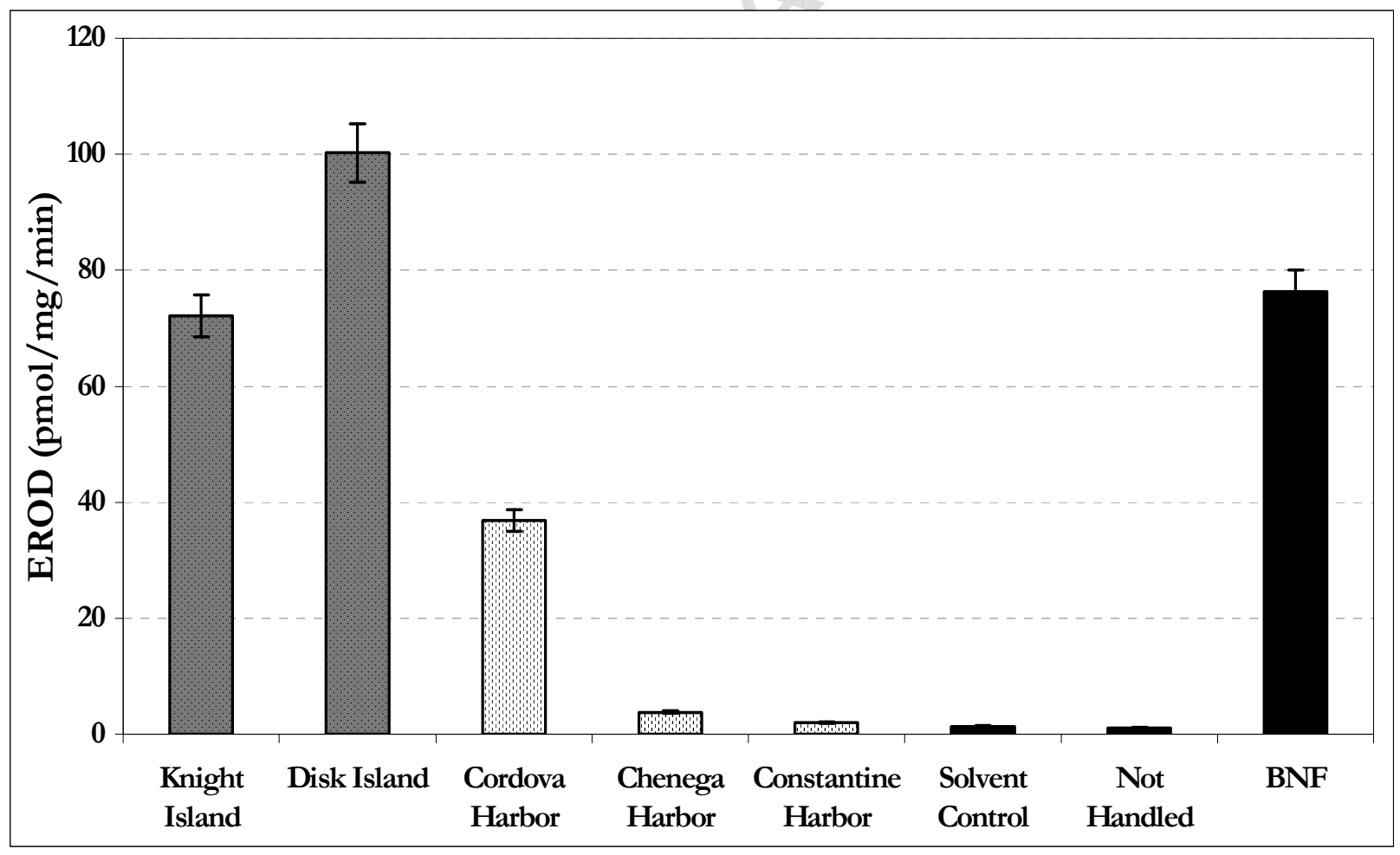


Table 1.

Specifications of Standard Semipermeable Membrane Device (SPMD)

from www.est-lab.com

Length (between the welds)

Width

Wall thickness

Tubing

Triolein

Membrane

Lipid:membrane

Weight of standard SPMD
$91.4 \mathrm{~cm}$

$2.5 \mathrm{~cm}$

$70-95 \mu \mathrm{m}$

Lay-flat low density polyethylene, additive

free, $10 \AA$ pores

$99 \%$ purity $(1.0 \mathrm{ml}$ used for standard $91.4 \mathrm{~cm}$

length)

surface area to total SPMD volume (SA-V)

ratio $\approx 90 \mathrm{~cm}^{2} / \mathrm{ml}$ or $\approx 460 \mathrm{~cm}^{2} / \mathrm{ml}$ triolein

mass ratio $\approx 0.2$

4.4 to 4.6 grams 